\title{
Medykalizacja starości na podstawie wybranych przykładów filmowych
}

\begin{abstract}
Abstrakt
Artykuł podejmuje tematykę zjawiska medykalizacji starości. W procesie medykalizacji następuje zamiana zjawiska naturalnego, rozwojowego, kulturowego czy społecznego w problem medyczny. Zakończeniem tegoż procesu jest moment, w którym dany atrybut powraca do kultury jako kwestia medyczna. Przykładem takiego powrotu jest tendencyjne przedstawianie osób starszych w przestrzeni publicznej, przekazach medialnych, szczególnie w filmach. Dostrzeżenie tego zjawiska jest pierwszym krokiem do bardziej refleksyjnego i krytycznego odbioru propagowanych treści, a w konsekwencji minimalizowania przejawiania zmedykalizowanych postaw wobec seniorów i procesu starzenia się. Celem artykułu jest opis zjawiska medykalizacji starości w filmach. Ze względu na rolę, jaką film odgrywa w modelowaniu postaw, ekspozycja i natężenie pewnych wzorców może pełnić rolę stygmatyzującą dla osób starszych. W celu zbadania, czy takie zjawisko występuje, wybrano 37 filmów i dokonano ich analizy pod względem wyróżnionych aspektów medykalizacji. Praca ma charakter empiryczny, a uzyskane wyniki wskazują na szerokie rozpowszechnienie medykalizacji starości jako motywu filmowego.
\end{abstract}

Słowa kluczowe: medykalizacja, starość, starzenie się, film.

\section{The Medicalization of Old Age Based on Selected Film Examples}

\begin{abstract}
The paper deals with the phenomenon of the medicalization of old age. In the process of medicalization, a natural, developmental, cultural, and social phenomenon changes into a medical problem. The process is concluded when a given attribute returns to
\end{abstract}

\footnotetext{
* Górnośląska Wyższa Szkoła Handlowa im. W. Korfantego w Katowicach.

** Politechnika Śląska w Gliwicach.
} 
culture as a medical issue. Examples of such a return include the tendentious image of elderly people in the public space and the media, in particular in films. Recognizing this phenomenon is the first step to a more critical and reflective reception of such messages and, as a consequence, using the medicalized approach to old age less and less frequently. The aim of the paper is to describe the phenomenon of medicalization of old age in films. Due to the role played by films in modelling of attitudes, the intensity of certain patterns may stigmatize the elderly. In order to examine whether such a phenomenon occurs, 37 films have been selected and analysed in terms of the selected aspects of medicalization. The work is empirical and the obtained results indicate that medicalization of old age is a very popular film motif.

Keywords: medicalization, old age, ageing, film.

\section{Wstęp}

Starość jest pojęciem niejednoznacznym, niejednorodnym, zatem trudnym do zdefiniowania, co wynika m.in. z braku jej bezspornych wskaźników, ujawniania się ich w różnym wieku, z odmiennym natężeniem, jakością, następstwem etc. Zazwyczaj odróżnia się starzenie się od starości. Starzenie się jest traktowane jako proces charakteryzujący się licznymi zmianami w sferze funkcjonowania biologicznego, psychicznego czy społecznego, natomiast starość rozumiana jest jako faza rozwojowa będąca skutkiem pierwszego (Zych 2012: 157-164; Pędich 1996: 9-13). Starzenie się i starość są zmienne (dynamiczne). Utożsamia się je z obniżaniem się energii życiowej, spadkiem wydolności organizmu, ograniczeniem lub utratą mobilności, osłabieniem sił immunologicznych, polichorobowością (wymiar biologiczny), ograniczeniem umiejętności przystosowania się do zmian, poczuciem osamotnienia, obniżeniem poczucia własnej wartości (starość psychiczna), spadkiem zasobów materialnych, koniecznością korzystania z pomocy innych (sfera ekonomiczna) czy alienacją, wykluczeniem, funkcjonowaniem na marginesie życia społecznego (tzw. starość społeczna) (Trafiałek 2006). Wydaje się, że proces starzenia się jest wartościowany mniej negatywnie niż starość jako taka. Być może wynika to z faktu, że starzenie się rozpoczyna się dość wcześnie (około 25.-30. roku życia), przebiega stopniowo, początkowo wręcz niezauważalnie (Zegarska, Woźniak 2006: 153-159). Mało tego, niektórzy badacze mówią wręcz, że starzenie się rozpoczyna się jeszcze przed narodzeniem (Allison et al 2016: 1968-1975) ${ }^{1}$. Negatywne postrzeganie starości może prowadzić do ageizmu² (Szukalski 2012:

\footnotetext{
1 Dane empiryczne uzyskane w badaniach eksperymentalnych na ciężarnych szczurach pokazują, że starzenie się naczyń wiąże się z reakcją utleniania ksantyny nawet przed urodzeniem oraz że matczyne leczenie allopurynolem, inhibitorem oksydazy ksantynowej, podczas ciąży może spowolnić starzenie naczyń u potomstwa.

2 „Ageizm to zestaw przekonań, uprzedzeń i stereotypów mających swe podstawy w biologicznym zróżnicowaniu ludzi, związanym z procesem starzenia się, które dotyczą kompetencji i potrzeb osób w zależności od ich chronologicznego wieku" (Szukalski 2012: 144).
} 
144), a ten z kolei do lęku, wstydu, wycofania czy desperackiej chęci zatrzymania młodości. Stygmatyzowanie, deprecjonowanie, dyskryminowanie osób starszych tworzy swoiste błędne koło w budowaniu i umacnianiu postaw względem starzenia się i starości, a przede wszystkim względem ludzi starszych. Traktowanie grona seniorów jako grupy homogenicznej, którą charakteryzują ograniczenia dotyczące życia codziennego, warunkowane głównie pogarszającym się stanem zdrowia, jest jednym z powodów rozwoju nowych gałęzi rynku, mających na celu „zaradzenie” starzeniu się, a przynajmniej osłabienie i spowolnienie jego skutków. Paradoksalnie jednak działania podejmowane w związku z promowaniem określonych zachowań seniorów (np. suplementowaniem diety, stosowaniem zestawów witamin, poddawaniem się zabiegom kosmetycznym i medycznym, etc.) wzmacniają przekonanie o słuszności negatywnego waloryzowania starości, co zwrotnie utwierdza ludzi w konieczności podejmowania działań ochronnych lub „leczących”3 starość. Widać to bardzo wyraźnie w zjawisku farmaceutykalizacji i medykalizacji starości (Fry 2017: 11-24).

Celem niniejszego artykułu jest ukazanie zmedykalizowanego obrazu starości w kulturze i przestrzeni publicznej na przykładzie analizy dzieł filmowych. Wybór (świadomy lub przypadkowy), odbiór, przeżywanie wytworów kultury nie pozostają obojętne dla żadnej ze stron (ani twórcy ani adresata), m.in. dlatego, że modelują one postawy uczestników wobec podejmowanego problemu czy zjawiska. W przypadku niekorzystnego, deprecjonującego czy lękotwórczego przekazu istnieje prawdopodobieństwo budowania negatywnych, a nawet patologicznych postaw wobec osób starszych, co może powodować z jednej strony narastanie obaw i frustracji związanych z własnym procesem starzenia się, a z drugiej, dalsze obniżanie się statusu seniorów i ich szeroko rozumianej jakości życia, co w kontekście zjawiska „siwienia kontynentu” staje się problemem społecznym, a nie tylko indywidualnym

\section{Medykalizacja starości}

Znaczącą rolę w kreowaniu rynku i opinii publicznej pełni zjawisko medykalizacji, czyli proces, w którym kulturowe i/lub społeczne konstrukty zyskują nowy, medyczny wydźwięk. Dzieje się to na kilku płaszczyznach. Jedną z nich jest płaszczyzna lingwistyczna. Tworząc nowe, medyczne definicje dla danego zjawiska, zmienia się jego wartościowanie i znaczenie. Sama definicja nie jest jednak wystarczająca

\footnotetext{
3 Prowadzone są prace kliniczne nad grupą tzw. leków antystarzeniowych (fisetyna, rapamycyna i metformina), które obecnie wykorzystywane są w medycynie w innych celach, np. rapamycyna jako lek immunosupresyjny $\mathrm{w}$ transplantologii, metformina jako lek przeciwcukrzycowy $\mathrm{w}$ leczeniu cukrzycy typu 2 zaś fisetyna w suplementacji przy chorobach nowotworowych jako fitozwiązek chemioprewencyjny aktywujący kinazę białkową zależną od adenozynomonofosforanu AMPK (Glossmann, Lutz 2019; Krzystyniak, Klonowska 2019).
} 
dla urealnienia i wprowadzenia zmian. Potrzebne jest też grono osób (specjalistów), które będą tworzyć relację pomiędzy podejściem teoretycznym, profesjonalistami a drugim człowiekiem będącym odbiorcą przekazywanych i proponowanych znaczeń (w przypadku starości przykładem może być wzrost zainteresowania takimi specjalnościami jak gerontologia czy andragogika). Ostatnim elementem jest instytucjonalizacja, czyli tworzenie instytucji odpowiadających zmedykalizowanemu zjawisku (Birrer, Tokuda 2017: 48-51).

Przejawy medykalizacji starości mogą przybierać wiele różnych form, od subtelnych i niemal niezauważalnych po wyrażane bezpośrednio i wprost. Równowaga pomiędzy zdrowiem i chorobą, wizerunek, dbanie o ciało, posiadanie dóbr materialnych czy odraczanie przejścia na emeryturę to tylko kilka z nich. Warto jednak wspomnieć, że samo zjawisko nie zachodzi jedynie w obszarze starości jako etapu życia. Z dostępnych badań można zauważyć postępującą medykalizację innych obszarów życia, m.in. seksualności (Tiefer 1996: 252-282), porodów (Cahill 2001: 334-342), samej ciąży (Barker 1998: 1067-1076) czy menopauzy (Kaufert, Gilbert 1986: 7-21).

W odniesieniu do medykalizacji starości na uwagę zasługuje artykuł Estes, Binney (1989: 587-596), którego celem był całościowy opis wspomnianego zjawiska. Autorki wyróżniły dwa aspekty biomedykalizacji. Pierwszym z nich był sposób, w jaki społeczeństwo odbiera zjawisko starzenia się. W takim ujęciu odbiór starości jest ściśle związany z terminologią medyczną i rozumiany jako problem medyczny. Drugim aspektem, nierozerwalnie związanym z pierwszym, są podejmowane działania wobec starości rozumianej w ujęciu już zmedykalizowanym. W ramach drugiego aspektu wyróżnione zostały 4 wymiary praktyk. Są to: zbiomedykalizowany obraz starzenia się w nauce, w obrębie profesji medycznych, w polityce publicznej i wiedzy potocznej. Społeczny odbiór starości w szczególny, zmedykalizowany sposób może zostać zaobserwowany w wytworach kultury, w tym filmach.

\section{Film a modelowanie postaw}

Film jest przejawem, odbiciem kultury, w której został wytworzony. Inspirowany codziennością łączy elementy realne i fikcyjne, tworząc nową rzeczywistość, pozostawiającą ślad w owej kulturze. Głębokie zakorzenienie filmu w kulturze i zjawisko kulturowego podłoża komunikacji filmu odnosi się do definicji kultury według J. Kozieleckiego (2002: 180), gdzie zjawisko jest systemem wzajemnie powiązanych wytworów materialnych i symbolicznych, które przekazują wartości, normy i znaczenia istotne dla danej społeczności (ibidem). Stąd też w filmie odbiorca znaleźć może zarówno wartości uniwersalne, jak i takie, które stoją w opozycji lub sprzeczności do jego kultury (Hopfinger 1980: 169). Dotyczy to również zjawiska medykalizacji. Medyczne transformacje znaczeń zwrotnie wracają w przekazach kulturowych, np. w dziełach filmowych, tym samym wzmacniając siłę 
i poszerzając krąg swych oddziaływań. Co więcej, moment, w którym dane zjawisko przestaje być postrzegane jako w pewien sposób zniekształcone, a zaczyna być uznawane jako naturalny element kultury, jest najwyższym stopniem medykalizacji.

Film jako dzieło posiada zróżnicowane grono odbiorców. Najszerszą publiczność posiadają filmy pochodzące z głównego nurtu (mainstream) i to one przekraczają nierzadko nie tylko granice państwa, w którym powstały, ale i kontynentów, trafiając do widzów na całym świecie. Tym samym treść, forma, idee, etc., które niosą, stanowią ważne źródło potencjalnych oddziaływań. Jak wynika z badań (Groeppel-Klein, Domke, Bartman 2006: 163-174), film niesie ze sobą możliwość modelowania postaw. To jaka postawa będzie modelowana przez film, zależy od konkretnego sposobu przedstawienia w nim danego zjawiska. Badania wskazują, że pojedyncze występowanie zjawisk (nawet patologicznych) nie ma znaczącego wpływu na widza (Mazur, Emmers-Sommer 2003: 157-181). Znacząca różnica zachodzi natomiast wtedy, kiedy wiele filmów powiela pewien schemat, przekazując te same postawy w różnych kontekstach (Stern 2005: 331-346). Dotąd prowadzone badania, których celem było wykazanie związku między postawą/zachowaniem a filmem, dotyczyły różnych zjawisk, od palenia papierosów (Sargent i in. 2002: 137-145), poprzez uprzedzenia (Behm-Morawitz, Mastro 2008: 131-146) do postawy wobec AIDS (Gilliam, Seltzer 1989: 261-265).

Możliwość połączenia edukacji z rozrywką przejawia się we wspólnym celu obu tych zjawisk, którym jest kształtowanie świadomości odbiorcy. W odniesieniu do edukacji cele szczegółowe koncentrują się wokół gromadzenia i strukturyzacji uzyskanej wiedzy. Natomiast rozrywka odwołuje się do emocji, potrzeb i odczuć (Wojniak 2015: 167-180). Modelem łączącym przedstawione zjawiska jest model edutainment. Jego celem jest edukacja odbiorcy za pomocą przekazu rozrywkowego. Zjawisko to nie ogranicza się jedynie do filmu i występowało już we wcześniejszych wiekach, np. w odniesieniu do antycznego dramatu czy XIX-wiecznej pozytywistycznej powieści z tezą. Teoretyczne umocowanie modelu edutainment odnosi się do teorii społecznego uczenia Alberta Bandury. W oparciu o nią charakter uczenia się jest poznawczy, a nie jedynie behawioralny oraz ściśle związany ze społecznym kontekstem. Człowiek obserwuje nie tylko dane zachowanie, ale także następstwa, jakie ono powoduje. Informacja, jaka została uzyskana z takiej obserwacji, może przyczynić się do podejmowania jednostkowych decyzji danej osoby i wiąże się z modelowaniem jej zachowań. W oparciu o klasyfikację Alberta Bandury jest to trzeci czynnik modelowania o charakterze symbolicznym (pozostałe dwa to: po pierwsze żywy model, czyli konkretna osoba wykonująca jakąś czynność, a po drugie instrukcje słowne). Do trzeciego czynnika możemy zaklasyfikować media, np. filmy, książki, radio, telewizję czy Internet (Bandura 1971: 2-7).

Film stanowi jedynie jeden ze sposobów edukacji przez rozrywkę. Ze względu na popularność i łatwą dostępność dociera on do szerokiego grona odbiorców. Co ważne, celem edukacji filmowej nie jest jedynie pobudzanie do refleksji, modelowanie zachowań czy wartościowanie pewnych obszarów, ale także nabywanie 
umiejętności rozmowy o zjawiskach poruszonych w filmie i krytycznego odbioru dzieła.

Analizowane w ramach niniejszej pracy filmy stanowią próbkę dzieł o możliwie największej liczbie odbiorców. Nie wszystkie z nich podejmują bezpośrednio temat starości. Czasem przewija się ona w tle pod postacią bohaterów pierwszoi drugoplanowych.

\section{Wybrane wymiary medykalizacji starości}

Medykalizacja starości przejawia się w różnych wymiarach (medycznym, społecznym, ekonomicznym, estetycznym itp.) Niektóre z nich pojawiają się częściej niż inne. Aby dokonać analizy dzieł filmowych pod kątem najczęściej poruszanych kwestii związanych z medykalizacją starości, niezbędne było ich wyróżnienie. W tym celu wybrano 6 artykułów opublikowanych w latach 2010-2018, które podejmowały tematykę medykalizacji starości i poddano je analizie. Przyjęto zasadę, według której występowanie określonego wymiaru skutkuje przyznaniem 1 punktu, zaś jego brak - brakiem punktu. Podejście to umożliwiło wyłonienie najczęściej pojawiających się wymiarów medykalizacji starości i w konsekwencji utworzenie ich listy wykorzystanej w kolejnym etapie, czyli w analizie wybranych filmów. Wyniki analizy z pierwszego etapu zamieszczone zostały w tabeli 1 .

Tabela 1 . Wymiary medykalizacji starości na podstawie artykułów naukowych

\begin{tabular}{|l|c|c|c|c|c|c|}
\hline \multicolumn{1}{|c|}{ Wymiary } & 1. & 2. & 3. & 4. & 5. & 6. \\
\hline $\begin{array}{l}\text { Ogólne ujęcie } \\
\text { medykalizacji starości }\end{array}$ & 1 & 1 & 1 & 1 & 1 & 1 \\
\hline $\begin{array}{l}\text { (Para) farmaceutyki } \\
\text { (medyczny) }\end{array}$ & 1 & 1 & 1 & - & 1 & 1 \\
\hline $\begin{array}{l}\text { Związki i relacje } \\
\text { (społeczny) }\end{array}$ & - & 1 & - & 1 & 1 & - \\
\hline Seksualność & - & 1 & 1 & 1 & - & - \\
\hline $\begin{array}{l}\text { Konsumpcjonizm; komercjalizacja } \\
\text { (ekonomiczny) }\end{array}$ & 1 & 1 & 1 & 1 & - & 1 \\
\hline $\begin{array}{l}\text { Śmierć; instytucjonalizacja } \\
\text { (egzystencjalny) }\end{array}$ & - & 1 & 1 & 1 & 1 & 1 \\
\hline $\begin{array}{l}\text { Stosunek do starości } \\
\text { (postawy) }\end{array}$ & 1 & 1 & - & 1 & 1 & 1 \\
\hline
\end{tabular}

Źródło: opracowanie własne. 
Do przedstawionej tabeli $1 \mathrm{w}$ przypisie dolnym zamieszczona została lista wykorzystanych artykułów ${ }^{4}$. Jak wynika z tabeli 1 ogólne ujęcie medykalizacji starości jest najczęściej podejmowanym wymiarem. Najmniej punktów zdobyły wymiary związków i relacji (społeczny) oraz seksualności osób starszych. Autorzy artykułów zwracali także uwagę na stosowanie farmaceutyków i parafarmaceutyków oraz konsumpcjonizm i komercjalizację starości. Podjęty został także wątek stosunku do starości zarówno osób starszych, jak i społeczeństwa (postawy względem starości), a także śmierci i instytucjonalizacji, np. w postaci domów spokojnej starości.

Starość zmedykalizowana, traktowana jako choroba, sugeruje osobom starszym konieczność konsultowania się i bycia w stałym kontakcie z lekarzami, poczynając od lekarzy rodzinnych, a kończąc nawet na chirurgach plastycznych. Nie ma nic złego $\mathrm{w}$ profilaktyce zdrowotnej i w leczeniu schorzeń, ale ujmowanie naturalnego obniżania się zasobów witalnych i zmian strukturalnych (np. skóry i jej wytworów) czy funkcjonalnych (np. dobowe zmiany snu i czuwania) w kategoriach problemów medycznych może prowadzić do gorszego funkcjonowania psychicznego, spowodowanego obawą i lękiem o własne zdrowie, obniżeniem samooceny, nadwrażliwością, anhedonią etc. Traktowanie starości w kategoriach chorobowych pociąga też za sobą konieczność wzmożonej opieki i kontroli nad seniorem. Powoduje to powstawanie coraz większej liczby domów opieki dla osób starszych, w których często opłata za pobyt przewyższa posiadaną przez seniora emeryturę, co stanowi z ekonomicznego punktu widzenia kolejny element, zmuszający osoby starsze do pozostawania w relacjach zależności z innymi (najczęściej z rodziną). W oparciu o raporty GUS z 2017 i 2018 r. dotyczące zakładów stacjonarnych pomocy społecznej pomiędzy rokiem 2016 a 2017 nastąpił 1,3\% wzrost mieszkańców, natomiast pomiędzy rokiem 2017 a 2018 wyniósł on 6,3\%.

Starość ujmowana jako choroba implikuje postawę walki, walki ze starością, a nawet samą śmiercią. Koncerny farmaceutyczne i kosmetologiczne nierzadko zapewniają, że konfrontacja ta może zakończyć się sukcesem. Zjawisko medykalizacji może powstać także oddolnie, kiedy na nacisk ze strony społeczeństwa odpowiada środowisko medyczne. Sprzyja temu wspomniana wcześniej instytucjonalizacja i kompleksowa opieka nad osobą chorą (starszą). Bycie pacjentem jest społecznie usankcjonowanym powodem, dla którego jednostka może zawiesić obowiązki względem rodziny czy pracy. Dodatkowo oddaje ona odpowiedzialność oraz kontrolę w ręce osoby zajmującej się leczeniem, co często jest pokłosiem biomedycznego modelu zdrowia i choroby. W modelu tym lekarz jest ekspertem, a zadaniem pacjenta jest jedynie dostosowanie się do jego zaleceń. Uznanie starości za chorobę daje także społeczne przyzwolenie na traktowanie osób starszych jako osoby chore. Patrząc na jednostkę przez pryzmat choroby zaciera się zróżnicowany obraz starości, a przecież nie jest ona okresem jednorodnym. Pomimo tego, że

\footnotetext{
4 1. Nowakowski, Nowakowska (2010); 2. Wieczorkowska (2018); 3. Wieczorkowska (2013); 4. Piłat (2017); 5. Kotlarska-Michalska (2016); 6. Tomaszawska-Laszczak i in. (2017).
} 
niektóre funkcje ulegają upośledzeniu, wiele innych pozostaje na niezmienionym poziomie przez całe życie. Jak wynika z badań, plastyczność mózgu spada, natomiast nigdy do wartości zera (McEwen 2016: 56-64). Oznacza to, że osoba starsza jest zdolna do uczenia się i wykształcenia nowych sposobów funkcjonowania, w celu skompensowania powstałych ubytków. Spostrzeganie osoby starej jako osoby chorej ogranicza, a czasem wręcz odbiera decyzyjność czy posiadanie rozwojowego celu życiowego. Wspomniane zmiany korespondują także ze zmianami w strukturze rodziny, co zmusza jej członków do wykształcenia nowych bądź zmodyfikowania obowiązujących ról kulturowych, z którymi osoby starsze były i są utożsamiane. Sprawia to, że brakuje skryptu kulturowego pozwalającego zdefiniować jednostce ten okres życia.

Zmienia się także stosunek do starości. Znaczące zmiany w ciągu ostatnich dekad zarówno przemysłowe i technologiczne, jak i kulturowo-społeczne, sprawiły, że osoby starsze zaczęły być postrzegane w negatywnych kontekstach. Wraz z wydłużaniem się życia wydłużył się także okres emerytalny osób starszych. Zjawisko starzenia się społeczeństwa sprawia ponadto, że osób starszych jest coraz więcej w porównaniu do osób aktywnych zawodowo. Rodzi to stereotyp osoby starszej żyjącej i leczącej się na koszt pracujących (w ramach budżetu państwa), w który znaczący wkład mają właśnie osoby aktywne zawodowo. Kolejnym elementem są zmiany na rynku pracy. Zjawiska globalizacji i indywidualizacji doprowadziły do tego, że preferowany jest pracownik młody, posiadający szerokie wykształcenie oraz znakomite umiejętności uczenia się nowych rzeczy, dostępny w coraz szerszym przedziale godzinowym, szczególnie gdy zwierzchnicy firmy znajdują się w innej strefie czasowej (Trask, 2018: 451-466). Powoduje to, że pracownik starszy postrzegany jest jako mniej kompetentny, kreatywny i zdolny do elastyczności. Wraz ze zmianami na rynku pracy zaistniały zmiany w społeczeństwie. Wspomniana już indywidualizacja, kładąca nacisk na sukces jednostki, doprowadziła do zmian w ogólnie posiadanych wartościach. Rozwój, kariera, sukces zawodowy zastąpiły bardziej kolektywne wartości, takie jak rodzina, posiadanie dzieci czy stabilna sytuacja zawodowa. Aspekt związków i relacji osób starszych także uległ zmianie. Rozluźnieniu więzi społecznych sprzyja także sekularyzacja społeczeństwa. Wartości tradycyjne, promowane na przykład przez religię chrześcijańską, tracą swoje umocowanie. Spowodowało to wzrost liczby osób starszych, które są osamotnione, mają ograniczone kontakty z rodziną lub jej nie posiadają. Może to skutkować deprywacją potrzeb, głównie przynależności czy bezpieczeństwa. Jak wynika z badań raportu PolSenior, im większa miejscowość, tym więcej osób starszych mieszka samotnie, w porównaniu do wsi, w miastach przeważają także rodziny jednopokoleniowe. Wyniki uzyskane z tego samego raportu wskazują także, że im człowiek jest starszy, tym słabsza staje się jego pozycja w rodzinie (większość badanych osób starszych deklarowała, że utrzymuje kontakty z rodziną częściej niż raz w miesiącu). Dodatkowo zauważono zjawisko kurczenia się społecznego kręgu, wynikającego częściowo z biologicznych przy- 
czyn, ale i konfliktów rodzinnych oraz rozproszenia członków rodziny. Posiadana sieć wsparcia jest głównie konstruowana w oparciu o najbliższą rodzinę i opiera się na zasadach wzajemności. Jak wynika z dostępnych analiz, znaczący odsetek osób nie posiada środków materialnych pozwalających na zaspokojenie podstawowych potrzeb, takich jak jedzenie czy opłacenie rachunków. Ciągły rozwój kultu młodości sprawia, że osoby starsze czują się mniej atrakcyjne, mają problemy z akceptacją siebie, starości, a także coraz częściej zmagają się z problemami psychicznymi wynikającymi z tego stanu rzeczy. Lęk przed byciem postrzeganym jako osoba starsza, a także wstyd wobec zmian zachodzących w ciele tworzą idealne środowisko dla rynku farmaceutycznego, kosmetologicznego itp., których produkty i reklamy nakręcają wir braku akceptacji dla starzenia się i starości.

Wymiar seksualności osób starszych także jest istotnym obrazem zjawiska medykalizacji starości. W oparciu o dostępne badania na aktywność seksualną osób starszych wpływa wiele czynników (Ostrowska 2019: 290-296). Nie tylko sprawność fizyczna i obecność chorób, ale także czynniki psychologiczne i społeczne odgrywają tu istotną rolę (Stankowska 2008). Wśród zmian fizycznych zachodzących u osób starszych można wyszczególnić występowanie menopauzy u kobiet i andropauzy u mężczyzn. Oprócz naturalnych procesów starzenia mogą pojawić się bariery związane z różnymi czynnikami biologicznymi, wśród nich najczęściej występującymi są zaburzenia erekcji, które mogą być też konsekwencją chorób przewlekłych, np. cukrzycy, nadciśnienia czy chorób serca. Pogarszająca się również praca zmysłów, ze szczególnym uwzględnieniem narządów wzroku i słuchu, może mieć wpływ na jakość i liczbę posiadanych kontaktów (Krasuski, Owczarek 2015: 89). Jednak czynniki fizyczne nie są jedynymi. Wśród psychologicznych zjawisk występują trudności w znalezieniu partnera po śmierci współmałżonka oraz niska społeczna akceptacja związków o dużej różnicy wieku. Dodatkowo istotnym elementem jest akceptacja siebie i poziom własnej samooceny, które mogą ulec obniżeniu w społecznym zbiomedykalizowanym ujmowaniu starości.

Z seksualnością osób starszych jest związany wymiar związków i relacji. Społeczny odbiór osób starszych jest często powiązany ze stereotypami, których krzywdząca rola może wpływać na jakość budowania relacji. Oprócz fizycznych barier znaczący wpływ ma także mobilność osób starszych. Wraz z wiekiem następuje zmniejszenie się grona sieci kontaktów społecznych, a w relacjach osób starszych najczęściej występują kontakty z rodziną. Dodatkowo, wraz z wydłużaniem się długości życia, wiele osób boryka się z samotnością po śmierci współmałżonka oraz stygmatyzacją $\mathrm{z}$ nią związaną. Występuje strach przed społecznym ostracyzmem w przypadku wejścia w kolejny związek oraz związane z wcześniej wymienioną seksualnością stereotypy takie jak na przykład ten, że u osób starszych potrzeby seksualne zanikają aż do całkowitego braku (Błajet 2018: 60).

Konsumpcja jako nieodłączny element życia sprawia także, że osoby starsze są coraz częściej definiowane przez to, co posiadają. Społecznie budowana spirala posiadania coraz większej ilości dóbr o coraz wyższej klasie stoi niejako w opozycji 
do rzeczywistości, z jaką zmagają się osoby starsze (Means, Langan 1996: 353358), gdyż wiele osób korzystających z emerytury jako jedynego przychodu otrzymuje znacząco mniejsze kwoty niż wynosi płaca minimalna.

Walka o zatrzymanie starzenia się nie dzieje się jedynie na płaszczyźnie zdrowotnej, ale także obejmuje kulturowe aspekty urody i mody. Osoby starsze zostają przeciwstawione kulturowemu przekazowi wspieranemu przez media, w którym osoby starsze są zdolne zatrzymać proces starzenia czy wręcz odwrócić zmiany, które są jego skutkiem. Zarówno producenci reklam kosmetycznych, jak i oferujący suplementy diety prześcigają się w obietnicach, za których spełnienie ma odpowiadać ich produkt. Znaczący jest fakt, że najczęściej odwołują się nie do faktów, a do manipulacji, opinii czy stanów emocjonalnych (Stefaniak-Hrycko 2012: 89-95).

\section{Analiza wybranych dzieł filmowych ${ }^{5}$}

Ostatnim elementem zmedykalizowania danego zjawiska jest sytuacja, w której powraca ono zwrotnie do kultury. Jednym z elementów kultury są właśnie dzieła filmowe. W niniejszym artykule przeanalizowano 37 filmów pochodzących zarówno ze Stanów Zjednoczonych, jak i z Europy. Kryterium wyboru filmów była jak największa liczba odbiorców. Zdecydowano się na takie kryterium, ponieważ im większa liczba odbiorców, tym większy stopień oddziaływania wybranych wymiarów medykalizacji, które mogą w nim wystąpić. Filmy, o których mówi się, że wpisują się w główny nurt właśnie przez to, że docierają do ogromnej liczby osób, mają szansę na największe modelowanie postaw. Liczba odbiorców sprawdzana była na dwóch portalach: www.imdb.com oraz www.filmweb.pl. Jeżeli film zarówno na jednym, jak i drugim portalu posiadał więcej niż 10 tysięcy ocen oraz w ogólnym opisie można było znaleźć elementy nawiązujące do starości, wtedy włączano go do analizy. Do analizy aspektów medykalizacji wybrano filmy zaprezentowane w tabeli 2. 18 filmów pochodziło jedynie ze Stanów Zjednoczonych, 7 filmów było

Tabela 2. Zestaw filmów analizowanych pod kątem medykalizacji starości

\begin{tabular}{|l|c|l|}
\hline \multicolumn{1}{|c|}{ Tytuł filmu } & $\begin{array}{c}\text { Rok } \\
\text { produkcji }\end{array}$ & \multicolumn{1}{c|}{ Pochodzenie } \\
\hline Choć goni nas czas & 2007 & USA \\
\hline Mr Nobody & 2009 & Kanada, Niemcy, Belgia, Francja \\
\hline Nebraska & 2013 & USA \\
\hline Być jak Flynn & 2013 & USA \\
\hline
\end{tabular}

\footnotetext{
5 Badanie współfinansowano ze środków Unii Europejskiej w ramach Europejskiego Funduszu Społecznego (POWR.03.02.00-00-I029).
} 
ANita GaŁUSZKa, ERYKA Probierz

\begin{tabular}{|c|c|c|}
\hline Wszyscy mają się dobrze & 2009 & USA \\
\hline Daleko od niej & 2006 & Kanada, USA \\
\hline To nie jest kraj dla starych ludzi & 2007 & USA \\
\hline Miłość & 2012 & Austria, Francja, Niemcy \\
\hline Żelazna dama & 2011 & Wielka Brytania, Francja \\
\hline Hotel Marigold & 2011 & $\begin{array}{l}\text { Wielka Brytania, Zjednoczone Emiraty } \\
\text { Arabskie, USA }\end{array}$ \\
\hline Drugi Hotel Marigold & 2015 & Wielka Brytania, USA \\
\hline Harry Brown & 2009 & Wielka Brytania \\
\hline Aż po grób & 2009 & Niemcy, Polska, USA \\
\hline A właśnie że tak & 2007 & USA \\
\hline Rodzina Savage & 2007 & USA \\
\hline Dopóki piłka w grze & 2012 & USA \\
\hline Robot i Frank & 2012 & USA \\
\hline Last Vegas & 2013 & USA \\
\hline Młodość & 2015 & Wielka Brytania, Szwajcaria, Francja, Włochy \\
\hline $\begin{array}{l}\text { Stulatek, który wyskoczył przez } \\
\text { okno i zniknął }\end{array}$ & 2013 & $\begin{array}{l}\text { Francja, Hiszpania, Rumunia, Szwecja, Wielka } \\
\text { Brytania }\end{array}$ \\
\hline Kwartet & 2012 & Wielka Brytania \\
\hline Dama $w$ vanie & 2015 & Wielka Brytania \\
\hline Moja staruszka & 2014 & Francja, USA \\
\hline Wszystko zostaje $w$ rodzinie & 2005 & Wielka Brytania \\
\hline Praktykant & 2015 & USA \\
\hline Twardziele & 2013 & USA \\
\hline Co ty wiesz o swoim dziadku & 2016 & USA \\
\hline Sezon na zabijanie & 2013 & Belgia, USA \\
\hline Idol & 2015 & USA \\
\hline Manglehorn & 2014 & USA \\
\hline Z miłości do... & 2012 & Wielka Brytania, Niemcy \\
\hline Miłość jest zagadkq & 2014 & USA, Francja \\
\hline Piknik z niedźwiedziami & 2015 & USA \\
\hline Przeboje i oldboje & 2013 & Czechy \\
\hline Elsa i Fred & 2014 & USA \\
\hline Złota jesień & 2016 & Wielka Brytania \\
\hline Zanim się spostrzeżesz & 2013 & USA \\
\hline
\end{tabular}

Źródło: opracowanie własne. 
wyprodukowanych zarówno w Stanach Zjednoczonych, jak i innych państwach, pozostałe obrazy reprezentowały głównie kinematografię europejską. Produkcje zostały stworzone w latach 2006-2016.

W celu oceny liczby wymiarów medykalizacji starości zastosowano metodę sędziów kompetentnych. Metoda ta zakłada wystąpienie co najmniej dwóch sędziów, czyli osób mających podstawową wiedzę na temat analizowanego zagadnienia, które niezależnie oceniają ten sam materiał. Uzyskane wyniki analiz dla każdego z sędziów są następnie łączone i sprawdzana jest ich zgodność. Im zgodność jest większa, czyli podobne oceny zostały zastosowane do wybranych dzieł, tym lepszy ostateczny wynik analizy. Statystyka obrazująca zgodność sędziów kompetentnych to W Kendalla. W przypadku niniejszej analizy, filmy oceniane były niezależnie pod względem wskazanych wcześniej wymiarów metodą sędziów kompetentnych, a uzyskany wynik zgodności dla dwóch sędziów wyniósł W Kendalla =0,83. Uzyskane wyniki wskazały, że 33 na 37 filmów zawierały co najmniej jeden wymiar medykalizacji, ale 28 na 37 zawierało więcej niż 3 wymiary. Filmy produkowane w USA miały 1,5 razy więcej odniesień do medykalizacji niż twórczość europejska. W filmach pojawiło się ponad 87 niepochlebnych opinii o starości i starzeniu się, a wszystkie te opinie pochodziły od bohaterów pierwszo- i drugoplanowych, nierzadko także będących osobami starszymi.

\section{UDZIAt ASPEKTÓW MEDYKALIZACJI}

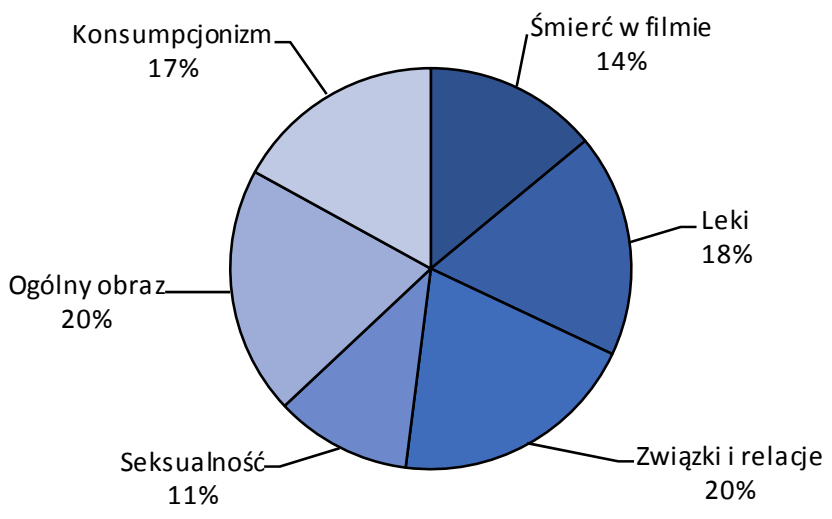

Ryc. 1. Udział wymiarów medykalizacji

Źródło: opracowanie własne

Rycina 1 przedstawia udział poszczególnych wymiarów medykalizacji w analizowanych dziełach filmowych. Najczęściej występującym zmedykalizowanym wymiarem było ogólne ujęcie medykalizacji starości (ok. 20\%), a następnie związki i relacje z osobami starszymi (prawie 19,5\%) oraz leki (farmaceutyki) i konsump- 
cjonizm (każde po ok. 18\%), co w tej sytuacji wydaje się spójne. Najmniej zmedykalizowana w tym przypadku była seksualność ludzi starych (ok. 11\%). Być może powodem tego jest traktowanie seniorów jako pozbawionych potrzeb seksualnych bądź też jako osób, dla których kwestie te mają niewielkie znaczenie lub wręcz są wstydliwe, nieprzyzwoite, a zatem niepożądane.

\section{Wnioski}

Celem niniejszego artykułu było zwrócenie uwagi na niepokojące zjawisko medykalizacji starości oraz na pokazanie obszaru obrazów filmowych, w których zjawisko to występuje. W literaturze zjawisko medykalizacji starości posiada swój model od 1989 r. W oparciu o model Estes i Binney oraz koncepcję edutainment przeprowadzono analizę filmów, których elementy mogą modelować postawy związane z medykalizacją starości. W tym celu, w oparciu o literaturę, wyróżniono różne wymiary medykalizacji starości w oparciu o literaturę. Następnie zastosowano metodę sędziów kompetentnych do zbadania występowania wyszczególnionych wymiarów w filmach. Filmy w wyniku powstawania i osadzenia w danej kulturze, w której są tworzone, prezentują niektóre z jej zmedykalizowanych aspektów życia. W wyniku przeprowadzonych analiz wyszczególniono 7 takich wymiarów. Należą do nich: ogólne ujęcie medykalizacji starości, farmaceutyki i suplementy przeznaczone dla osób starszych (wymiar medyczny), związki i relacje osób starszych (wymiar społeczny), seksualność osób starszych, konsumpcjonizm (wymiar ekonomiczny), umieranie i śmierć (wymiar egzystencjalny) oraz stosunek do starości (wymiar związany z postawami). Oceniono 37 filmów, z których aż 33 zawierały co najmniej jeden wątek związany $\mathrm{z}$ medykalizacją. Zbadano także popularność występowania poszczególnych aspektów oraz niektóre różnice związane z krajem pochodzenia filmu, (najczęściej starość traktowana jest jako choroba, zaś medykalizacja jest znacznie częstsza w produkcjach amerykańskich niż europejskich).

Można ostrożnie twierdzić, że zjawisko medykalizacji starości przeniknęło do kultury masowej, a jego miejsce w sztuce filmowej zajmuje znaczące spectrum, co może rodzić nieprawdziwe i niewłaściwe postawy względem starzenia się i starości, budząc niepokój odbiorców.

\section{Zakończenie}

Podsumowując, zjawisko medykalizacji nie jest jednorodne i dotyczy wielu sfer życia, co ułatwiło przeniknięcie jej do kultury masowej. Znaczące miejsce w tej kulturze zajmują filmy. Świadomy odbiór dzieła filmowego pozwala na zauważenie i refleksyjne podejście do zagadnienia medykalizacji starości. Jest to szczególnie istotne w kontekście innych elementów budujących negatywny stosunek do osób 
starszych, jak np. ageizm, czyli dyskryminacja ze względu na wiek. Osoby starsze stanowią coraz większy odsetek społeczeństw Europy i Ameryki Północnej, a tendencja ta ma wzrastać $w$ przyszłych latach. Niepokojące jest więc wybiórcze i tendencyjne pokazywanie rzeczywistości oraz tworzenie negatywnych postaw wobec starości i jej przejawów. Zinternalizowanie niekorzystnych postaw względem starości przez osoby starsze może utrudniać akceptację pojawiających się w ich życiu zmian, obniżać samoocenę, poczucie skuteczności i kontroli własnego życia, wzmacniać poczucie wstydu, dyskryminacji i wykluczenia, zaś uwewnętrznienie tych postaw przez osoby młode może kreować obawę i lęk przed przyszłością. W obu sytuacjach mogą pojawić się trudności w pokonywaniu wyzwań rozwojowych i w normalnym, twórczym i satysfakcjonującym funkcjonowaniu w świecie, nadawaniu sensu własnemu istnieniu i osiąganiu dobrej jakości życia.

\section{Bibliografia}

Bandura A. (1971) Social Learning Theory, Morristown, New York.

Barker K. K. (1998) A ship upon a stormy sea: The medicalization of pregnancy, "Social Science \& Medicine", nr 47 (8), s. 1067-1076.

Behm-Morawitz E., Mastro D. E (2008) Mean girls? The influence of gender portrayals in teen movies on emerging adults' gender-based attitudes and beliefs, "Journalism \& Mass Communication Quarterly", nr 85 (1), s. 131-146.

Błajet P. (2018) Zdrowie i seks seniorów, Toruń, Wydawnictwo Naukowe Uniwersytetu Mikołaja Kopernika.

Birrer R. B., Tokuda Y. (2017) Medicalization: A historical perspective, "Journal of General and Family Medicine", nr 18 (2), s. 48-51.

Cahill H. A. (2001) Male appropriation and medicalization of childbirth: an historical analysis, "Journal of Advanced Nursing”, nr 33 (3), s. 334-342.

Estes C. L., Binney E. A. (1989) The biomedicalization of aging: Dangers and dilemmas, “The Gerontologist", nr 29 (5), s. 587-596.

Fry C. L. (2017) The social construction of age and the experience of aging in the late twentieth century, "In New Dynamics in Old Age", nr 2, s. 11-24.

Gilliam A., Seltzer R. (1989) The efficacy of educational movies on AIDS knowledge and attitudes among college students, "Journal of American College Health", nr 37 (6), s. 261-265. 
Glossmann H., Lutz O. (2019) Metformin and Aging: A Review, “Gerontology", nr 65, s. 581-590.

Groeppel-Klein A., Domke A., Bartmann B. (2006) Pretty Woman Or Erin Brockovich? Unconscious and Conscious Reactions to Commercials and Movies Shaped By Fairy Tale Archetpyes - Results From Two Experimental Studies, "ACR North American Advances", s. $163-174$.

Hopfinger M. (1980) Komunikacja filmowa a wzory kultury literackiej w: Z badań porównawczych nad filmem, A. Helman, A. Gwóźdź (red.), Warszawa-Katowice-Kraków, s. 169.

Kaufert P. A., Gilbert P. (1986) Women, menopause, and medicalization, "Culture, Medicine and Psychiatry", nr 10 (1), s. 7-21.

Kotlarska-Michalska A. (2016) Specyfika opieki nad najstarszym pokoleniem a polityka społeczna wobec starości, "Przegląd Socjologiczny”, nr 65 (2), s. 123-142.

Krasuski T., Owczarek K. (2015) Seksualność seniorów w: Pogoda na starość. Podręcznik skutecznego wspierania seniorów, K. Owczarek, M. A. Łazarewicz (red.), Warszawa, Wydawnictwo Wolters Kluwer, s. 86-96.

Krzystyniak K., Klonowska J. (red.) (2019) Nowe trendy w dietetyce, Warszawa, WSIiZ.

Mazur M. A., Emmers-Sommer T. M. (2003) The effect of movie portrayals on audience attitudes about nontraditional families and sexual orientation, "Journal of Homosexuality", nr 44 (1), s. 157-181.

McEwen B. S. (2016) In pursuit of resilience: stress, epigenetics, and brain plasticity, "Annals of the New York Academy of Sciences", nr 1373 (1), s. 56-64.

Means R., Langan J. (1996) Money 'handling', financial abuse and elderly people with dementia: implications for welfare professionals, "Health \& Social Care in the Community", nr 4 (6), s. 353-358.

Nowakowski M., Nowakowska L. (2010) Medykalizacja starości: dylematy i zagrożenia w: P. Szukalski, D. Kałuża, Jakość życia seniorów w XXI wieku. Ku aktywności, Łódź, Wydawnictwo Uniwersytetu Łódzkiego, s. 206-218.

Ostrowska M. (2019) Aktywność seksualna osób starszych - jakość życia i stereotypy, “Kwartalnik Naukowy Fides et Ratio", nr 3 (39), s. 290-296.

Piłat A. (2017) Społeczne konsekwencje medykalizacji procesu starzenia się na przykładzie analizy portalu Senior, "Przegląd Socjologiczny", nr 66 (1), s. 135-153. 
Pędich W. (1996) Wskazania i przeciwwskazania do aktywności ruchowej osób starszych w: A. Jopkiewicz, Aktywność ruchowa osób starszych, Kielce, Wydawnictwo WSP, s. 9-13.

Sargent J. D., Dalton M. A., Beach M. L., Mott L. A., Tickle J. J, Ahrens M. B., Heatherton T. F. (2002) Viewing tobacco use in movies: does it shape attitudes that mediate adolescent smoking?, "American Journal of Preventive Medicine”, nr 22 (3), s. 137-145.

Sontag S. (2018) The double standard of aging, "In The Other Within Us", Routledge, s. 19-24.

Stankowska I. (2008) Funkcjonowanie seksualne człowieka w okresie starzenia się i starości, „Przegląd Terapeutyczny” nr 4.

Stefaniak-Hrycko A. (2012) Starość w reklamie telewizyjnej - śmieszy czy przeraża?, „Nowiny Lekarskie”, nr 81 (1), s. 89-95.

Stern S. R. (2005) Messages from teens on the big screen: Smoking, drinking, and drug use in teen-centered films, "Journal of Health Communication", $\mathrm{nr} 10$ (4), s. 331-346.

Szukalski P. (2012) Solidarność pokoleń. Dylematy relacji międzypokoleniowych, Łódź, Wydawnictwo Uniwersytetu Łódzkiego.

Tiefer L. (1996) The medicalization of sexuality: Conceptual, normative, and professional issues, "Annual Review of Sex Research", nr 7 (1), s. 252-282.

Tomaszawska-Laszczak M., Paprocka-Borowicz M., Dorna K., Gnus E., Kurzalewska A., Czerwiński P., Gnus J. (2017) Medykalizacja osób starszych w: Libor G., Starość nie jednq ma twarz: Badania interdyscyplinarne nad starością, Wydawnictwo Internetowe e-bookowo, s. 181-196.

Trafiałek E. (2006) Starzenie się i starość: wybór tekstów z gerontologii społecznej, Kielce, Wydawnictwo Uczelniane, Wszechnica Świętokrzyska.

Trask B. S. (2018) Integrating Life Course, Globalization, and the Study of Racial and Ethnic Families, “Journal of Family Theory \& Review”, nr 10 (2), s. 451-466.

Wieczorkowska M. (2013) Czy starość jest chorobq̨? - medykalizacja starości w Polsce, „Przegląd Socjologiczny”, nr 62 (2), s. 109-134.

Wieczorkowska M. (2018) Społeczne i ekonomiczne konsekwencje medykalizacji starości i starzenia się, „Folia Oeconomica”, nr 2 (334), s. 19-37.

Wojniak J. (2015) Edutainment i edukacja filmowa jako narzędzia kształtowania tożsamości oraz postaw dzieci i młodzieży, „Państwo i Społeczeństwo”, nr 15 (1), s. 167-180. 
Zegarska B. Woźniak M. (2006). Przyczyny wewnątrzpochodnego starzenia się skóry, „Gerontologia Polska”, nr 14/4, s. 153-159.

Zych A. (2012) Globalne starzenie się oraz potrzeby społeczne, kulturalne i edukacyjne ludzi starych - wyzwanie dla uniwersytetów trzeciego wieku, „Teraźniejszość - Człowiek - Edukacja : kwartalnik myśli społeczno-pedagogicznej”, nr 2 (58), s. 157-164.

\section{Źródła internetowe}

Allison B. J., Kaandorp J. J., Kane A. D., Camm E. J., Lusby C., Cross C. M., Nevin-Dolan R., Thakor A. S., Derks J. B., Tarry-Adkins J. L., Ozanne S. E., Giussani D. (2016), Divergence of mechanistic pathways mediating cardiovascular aging and developmental programming of cardiovascular disease, "The FASEB Journal"; DOI: 10.1096/ fj.201500057 [dostęp: 5.03.2020].

PolSenior (PBZ-MEiN-9/2/2006) Aspekty medyczne, psychologiczne, socjologiczne i ekonomiczne starzenia się ludzi w Polsce, http://gerontologia.org.pl/wpcontent/ uploads/pliki/ol/polsenior.pdf [dostęp: 13.02.2020].

Raport Głównego Urzędu Statystycznego: Zakłady stacjonarne pomocy społecznej w 2017 roku, https://stat.gov.pl/download/gfx/portalinformacyjny/pl/ defaultaktualnosci/5487/18/2/1/zaklady_stacjonarne_pomocy_spolecznej_w_2017_ roku.pdf [dostęp: 13.02.2020].

Raport Głównego Urzędu Statystycznego: Zakłady stacjonarne pomocy społecznej w 2018 roku, https://stat.gov.pl/obszary-tematyczne/warunki-zycia/ubostwopomoc-spoleczna/zaklady-stacjonarne-pomocy-spolecznej-w-2018-roku,18,3.html [dostęp: 13.02.2020].

https://www.filmweb.pl/ [dostęp: 13.02.2020].

https://www.imdb.com/ [dostęp: 13.02.2020] 